\title{
Endothelin-1 is an Autocrine/Paracrine Growth Factor for Human Cancer Cell Lines
}

\author{
Masayoshi Shichiri, Yukio Hirata, Tohru Nakajima,“ Kenji Ando, Taihei Imai, \\ Masashi Yanagisawa, ${ }^{\ddagger}$ Tomoh Masaki, ${ }^{*}$ and Fumiaki Marumo \\ Departments of Medicine and ${ }^{*}$ Biomaterials Science, Tokyo Medical and Dental University, Bunkyo-ku, Tokyo 113, and \\ ${ }^{\ddagger}$ Department of Pharmacology, Institute of Basic Medical Science, University of Tsukuba, Ibaraki 305, Japan
}

\begin{abstract}
We studied whether a novel vasoconstrictor peptide, endothelin-1 (ET-1), is synthesized by and released from human carcinoma cell lines, and whether ET-1 stimulates proliferation of these tumor cells. ET-1-like immunoreactivity was released from both HeLa and HEp-2 cells as a function of time. Reverse-phase HPLC of the conditioned media from HeLa cells revealed a major peak coeluting with standard ET-1. Northern blot analysis demonstrated the expression of mRNA for ET-1 precursor in both tumor cell lines. Both cell lines contained a single class of specific binding sites for ET-1. ET-1 dose-dependently induced increases in cytosolic free $\mathrm{Ca}^{2+}$ concentration in fura-2-loaded tumor cells, whose effect was completely abolished by chelating extracellular $\mathrm{Ca}^{2+}$ or by $\mathrm{Ca}^{2+}$-channel blocker. ET-1 stimulated proliferation of the quiescent cell lines in a dose-dependent manner, whose effect was inhibited by $\mathrm{Ca}^{2+}$-channel blocker. Polyclonal antibody for ET-1 inhibited proliferation of these cell lines, whereas nonimmune serum had no effect. These results demonstrate that ET-1 is synthesized by and released from human epithelial carcinoma cell lines, and that exogenous and endogenous ET-1 stimulates proliferation of the cells possibly through $\mathrm{Ca}^{2+}$ influx, suggesting its role as an autocrine/paracrine growth factor for certain tumor cells. (J. Clin. Invest. 1991. 87:1867-1871.) Key words: radioimmunoassay • receptor $\bullet$ cystolic free $\mathrm{Ca}^{2+}$ concentration • cell proliferation $\cdot$ Northern blot analysis
\end{abstract}

\section{Introduction}

Endothelin-1 (ET-1), ${ }^{1}$ originally characterized from the supernatant of cultured porcine endothelial cells, is a potent vasoconstrictor/pressor peptide (1). Subsequent cDNA cloning of human genomic library revealed three isopeptides, termed ET-

Address correspondence to Dr. Yukio Hirata, Second Department of Internal Medicine, Tokyo Medical and Dental University, 1-5-45, Yushima, Bunkyo-ku, Tokyo 113, Japan.

Received for publication 22 June 1990 and in revised form 31 December 1990.

1. Abbreviations used in this paper: $\left[\mathrm{Ca}^{2+}\right]_{i}$, cytosolic free $\mathrm{Ca}^{2+}$ concentration; ET-1, endothelin-1; LI, like immunoreactivity.

J. Clin. Invest.

(C) The American Society for Clinical Investigation, Inc.

0021-9738/91/05/1867/05 \$2.00

Volume 87, May 1991, 1867-1871
1, ET-2, and ET-3 (1, 2). Specific receptors for ET-1 are distributed not only in cardiovascular system, but also in a wide variety of tissues (3), suggesting its diverse physiological functions. Recently, it has been reported that ET-1 stimulates proliferation of rat vascular smooth muscle cells (4), fibroblasts (5), and glomerular mesangial cells (6), and the expression of protooncogenes (c-myc, c-fos) in these cells, suggesting its potential role as a growth factor. At present, no information is yet available whether ET-1 is produced by carcinoma cells and acts by themselves. In the present study, we demonstrate that two epithelial carcinoma cell lines derived from human cervix (HeLa) and larynx (HEp-2) express mRNA for ET-1 precursor, and release ET-1 into medium, and further show that both tumor cells possess specific ET-1 receptors through which ET-1 stimulates cell proliferation possibly via influx of extracellular $\mathrm{Ca}^{2+}$.

\section{Methods}

Cell culture. HeLa cells (American Type Culture Collection, Rockville, MD) were cultured in MEM supplemented with $2 \mathrm{mM}$ glutamine and $10 \%$ fetal bovine serum (FBS), and HEp-2 cells (ATCC) in Eagle's MEM with Earle's balanced salt solution and $10 \% \mathrm{FBS}$ at $37^{\circ} \mathrm{C}$ in a $95 \%$ room air $-5 \% \mathrm{CO}_{2}$ humidified incubator. Medium was changed every 2-3 d. After reaching confluency, cells were replaced with a serum-free MEM for $2 \mathrm{~d}$. The conditioned media were pooled and stored at $-40^{\circ} \mathrm{C}$ until processed for extraction. Cell number was measured by Coulter Counter Model ZM (Coulter Electronics, Inc., Hialeah, FL).

Extraction of ET-1. For chromatographic analysis, the pooled conditioned media $(100 \mathrm{ml})$ were acidified with $0.1 \%$ trifluoroacetic acid (TFA), and the supernatant applied to Spe $\mathrm{C}_{8}$ cartridge (J. T. Baker Chemical Co., Phillipsburg, NJ) and eluted with $2 \mathrm{ml} 60 \%$ acetonitrile/ $0.1 \%$ TFA, as reported previously (7). The eluates were evaporated to dryness and subjected to reverse-phase HPLC. The recovery of synthetic ET-1 during the extraction procedure was $77 \%$.

Radioimmunoassay (RIA). ET-1-like immunoreactivity (LI) was determined by specific RIA for ET-1 as reported (7). The antibody used in the present RIA mainly recognizes the $\mathrm{COOH}$-terminal $\mathrm{Trp}^{21}$ residue of ET-1, and cross-reacts fully with ET-2 and ET-3, but not with big ET-1, or other polypeptide hormones. The final dilution of antiserum was 1:150,000. The bound ligands were separated from the free ones by the double antibody method. The sensitivity of ET-1 RIA was $1.0 \mathrm{fmol} /$ tube, and the $50 \%$ intercept was $14 \mathrm{fmol} /$ tube. The intra- and interassay variations were 3.2 and $8.6 \%$, respectively.

Reverse-phase HPLC. The extract of the conditioned media from HeLa cells was loaded on a column $\left(0.45 \times 25 \mathrm{~cm}, 5 \mu \mathrm{m}, \mathrm{C}_{18}\right.$, Nucleosil, Macherey-Nagel, Düren, FRG) eluted with a linear gradient (15$60 \%$ ) of acetonitrile in $0.09 \%$ TFA for $60 \mathrm{~min}$ at a flow rate of $1 \mathrm{ml} /$ min. After evaporation, each eluate was subjected to ET-1 RIA. The recovery of standard ET-1 was $96 \%$. 
Northern blot analysis. Total RNA from confluent cells was extracted with $\mathrm{LiCl}$-urea and subjected to poly $(\mathrm{A})^{+} \mathrm{RNA}$ selection. Poly(A) ${ }^{+}$RNA $(10 \mu \mathrm{g})$ was fractionated in a formaldehyde $/ 1.1 \%$ agarose gel electrophoresis and transferred to a GeneScreen Plus membrane (DuPont Co., Wilmington, DE). The probe was $3^{\prime}$ noncoding exon from cloned human preproET-1 gene (1), labeled with $\left[{ }^{32} \mathrm{P}\right] \mathrm{dCTP}$ (sp act, 3,000 Ci/mmol; Amersham International, Amersham, UK) by the random-primed labeling method, and was incubated at $42^{\circ} \mathrm{C}$ for 16 $h$ with membranes in hybridization buffer containing $1 \mathrm{M} \mathrm{NaCl} / 50 \%$ (vol/vol) formamide $/ 1 \% \mathrm{SDS} / 250 \mu \mathrm{g} / \mathrm{ml}$ of salmon sperm DNA. The membranes were washed with $0.3 \mathrm{M} \mathrm{NaCl} / 30 \mathrm{mM}$ sodium citrate/ $1 \%$ SDS at $60^{\circ} \mathrm{C}$, and autoradiographed on a Kodak XAR-1 film with an intensifying screen at $-80^{\circ} \mathrm{C}$ for $8-16 \mathrm{~h}(8)$.

Binding experiments. Binding experiments were performed essentially in the same manner as previously described (9). Confluent cells $\left(10^{6}\right.$ cells) were washed twice with HBSS containing $0.1 \% \mathrm{BSA}$, and incubated at $37^{\circ} \mathrm{C}$ for $2 \mathrm{~h}$ with $1.3 \times 10^{-11} \mathrm{M}^{125} \mathrm{I}-\mathrm{ET}-1$ (sp act, 2,000 $\mathrm{Ci} / \mathrm{mmol}$; Amersham International) in the absence and presence of various concentrations of unlabeled ET-1 (Peptide Institute, Osaka Japan). The cells were then washed twice with ice-cold HBSS, solubilized with $1 \mathrm{~N} \mathrm{NaOH}$ at $37^{\circ} \mathrm{C}$, and the cell-bound radioactivity was measured. Specific binding was calculated as total binding minus nonspecific binding in the presence of excess unlabeled ET-1. The apparent dissociation constant $\left(K_{\mathrm{d}}\right)$ and maximal binding capacity $\left(B_{\max }\right)$ were calculated by Scatchard analysis of binding data.

Determination of intracellular $\mathrm{Ca}^{2+}$ concentration $\left(\left[\mathrm{Ca}^{2+}\right]_{i}\right)$. Confluent HeLa and HEp-2 cells which had been deprived of FBS for $48 \mathrm{~h}$ were dispersed with $0.25 \%$ trypsin and $0.02 \%$ EDTA, and incubated with $5 \mu \mathrm{M}$ fura-2 acetoxymethylester (Dojin Chemical, Kumamoto, Japan) at $37^{\circ} \mathrm{C}$ for $20 \mathrm{~min}$ in HBSS. Suspended fura-2-loaded cells were washed, and incubated for $20 \mathrm{~min}$ in physiological salt solution ( $130 \mathrm{mM} \mathrm{NaCl}, 5 \mathrm{mM} \mathrm{KCl}, 1 \mathrm{mM} \mathrm{MgCl}$, $1.5 \mathrm{mM} \mathrm{CaCl}_{2}$, and $20 \mathrm{mM}$ Hepes, pH 7.4), containing $0.5 \%$ BSA and $10 \mathrm{mM}$ glucose to allow for intracellular dye cleavage. Fluorescence of fura-2-loaded suspended cells $\left(5 \times 10^{6}\right.$ cells $\left./ \mathrm{ml}\right)$ was measured at $37^{\circ} \mathrm{C}$ using continuous rapid alternating excitation from dual monochromators (340 and $380 \mathrm{~nm}$ ), and emission at $505 \mathrm{~nm}$ (CAF-100, Japan Spectroscopic Co. Ltd., Tokyo) as reported (9). Fluorescent measurement was converted to $\left[\mathrm{Ca}^{2+}\right]$ by determining the maximal fluorescence $\left(R_{\max }\right)$ with $10 \%$ Triton $\mathrm{X}-100$, followed by the minimal fluorescence $\left(R_{\min }\right)$ with $15 \mathrm{mM}$ EGTA, $\mathrm{pH}$ 10.5. The following formula was used: $\left[\mathrm{Ca}^{2+}\right]_{\mathrm{i}}=K_{\mathrm{d}}[(R$ $\left.\left.-R_{\min }\right) /\left(R_{\max }-R\right)\right] \times\left(380_{\min } / 380_{\max }\right)$ assuming that the $K_{\mathrm{d}}$ for the fura-2: $\mathrm{Ca}^{2+}$ complex is $224 \mathrm{nM}$ at $37^{\circ} \mathrm{C}(10)$.

Cell proliferation. Cells were seeded into 12-well cluster dishes (2.9 $\times 10^{4}$ cells/well). After $24 \mathrm{~h}$, the cells were washed, and replaced with 2 $\mathrm{ml}$ serum-free MEM with or without ET-1 and incubated for the indicated times. After completion, cells were trypsinized, and the cell number was measured by Coulter Counter. To determine whether the antibody for ET-1 used for RIA affects the cell proliferation, tumor cells which had been replaced with fresh MEM containing $0.2 \%$ FBS (HeLa cells) or $3 \%$ FBS (HEp-2 cells) were incubated in the absence and presence of various dilutions $(1: 1,000-1: 1,000,000)$ of rabbit ET-1 antiserum and nonimmune rabbit serum $(1: 1,000)$ as control. After $72 \mathrm{~h}$, cell number was determined.

Statistical analysis. Results were expressed as mean \pm SEM. Statistical analysis was performed by Student's $t$ test for nonpaired data.

\section{Results}

Serial dilution curves generated by extract of the conditioned media of both HeLa and HEp-2 tumor cells were parallel to that of standard ET-1 in RIA (data not shown). HeLa cells under a serum-free condition released ET-1-LI as a function of time, reaching a plateau after $24 \mathrm{~h}$ (Fig. 1). Presence of FBS in the incubation medium potentiated the amounts of ET-1-LI released from both cells; the rates of ET-1-LI released from

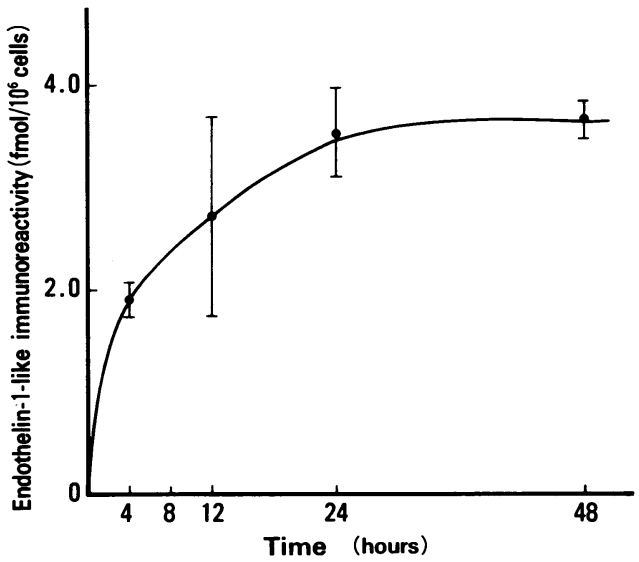

Figure 1. Release of ET-1-LI from HeLa cells as a function of time under a serum-free condition. Each point represents the mean of four to eight dishes; bars indicate SEM.

HeLa and HEp-2 cells under a serum-free condition were $3.53 \pm 0.44$ and $22.3 \pm 4.3 \mathrm{fmol} / 24 \mathrm{~h} / 10^{6}$ cells $(n=4)$, respectively, whereas they were $220 \pm 14$ and $190 \pm 26 \mathrm{fmol} / 24 \mathrm{~h} / 10^{6}$ cells $(n=3)$ in the presence of $10 \%$ FBS

Reverse-phase HPLC profile of ET-1-LI in extract of the conditioned media from HeLa cells is shown in Fig. 2. Reversephase HPLC revealed two ET-1-LI components, one major component coeluting with standard ET-1 and the other having yet uncharacterized retention time.

Northern blot analysis of poly(A) ${ }^{+}$RNA from both tumor cells using cDNA from human prepro-ET-1 as a probe is shown in Fig. 3. A single hybridization band corresponding to the size $(2.3 \mathrm{~kb})$ of mRNA coding for human prepro-ET-1 was demonstrated in both cells.

To characterize the specific binding sites for ET-1 in these tumor cells, binding study using ${ }^{125}$ I-ET- 1 as a radioligand was performed. Unlabeled ET-1 competitively inhibited the bind-

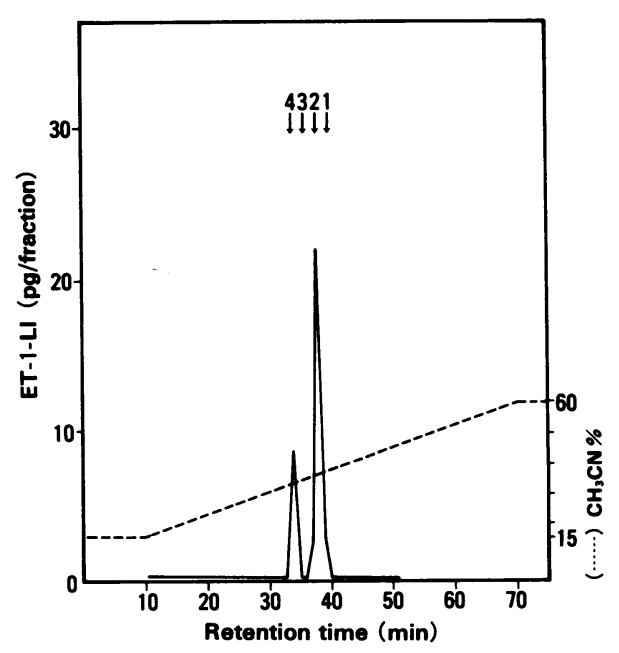

Figure 2. Reverse-phase HPLC profile of ET-1-LI in extract of the conditioned media from HeLa cells. (Solid line) ET-1-LI in each fraction. (Dashed line) A linear gradient (15-60\%) of acetonitrile. Elution positions of standard ET-2, ET-1, big ET-1, and ET-3 are indicated by arrows $1,2,3$, and 4 , respectively. 


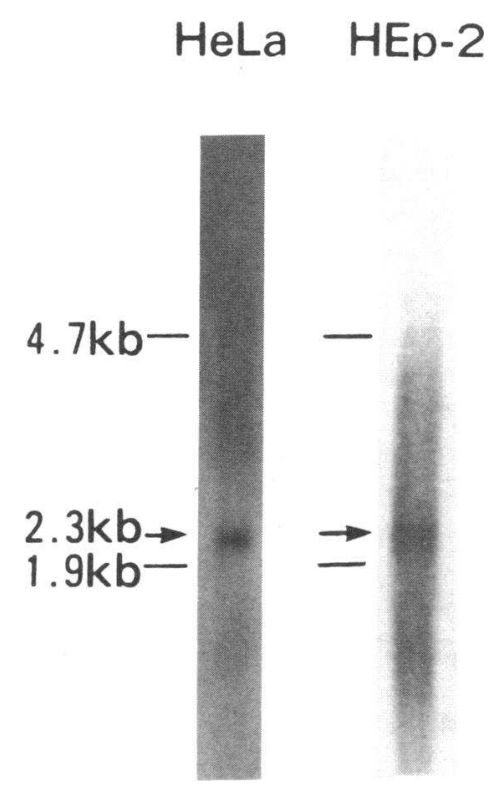

Figure 3. Northern blot analysis of HeLa and HEp2 cell mRNA.

Poly(A) ${ }^{+}$RNA $(10 \mu \mathrm{g})$ was hybridized with human prepro-ET-1 cDNA as a probe. A single band with a size of $2.3 \mathrm{~kb}$ was observed in both tumor cells. Size markers in kilobases are indicated on the left.

ing of ${ }^{125}$ I-ET-1 to both cells (Fig. 4). Scatchard analysis indicated the presence of a single class of noninteracting binding sites for ET- 1 in both cells: the apparent $K_{\mathrm{d}}$ and $B_{\max }$ were 1 $\times 10^{-10} \mathrm{M}$ and $6.8 \times 10^{5}$ sites/cell (HeLa cells), and $3 \times 10^{-7} \mathrm{M}$ and $1.4 \times 10^{10}$ sites/cell (HEp-2), respectively.

The effect of ET-1 on $\left[\mathrm{Ca}^{2+}\right]_{i}$ in these two cell lines was studied by measuring changes of fura-2-Ca ${ }^{2+}$ fluorescence (Fig. 5). The basal $\left[\mathrm{Ca}^{2+}\right]_{\mathrm{i}}$ was $190.9 \pm 7.2 \mathrm{nM}(n=34)$ in HeLa cells. ET-1 induced gradual increase in $\left[\mathrm{Ca}^{2+}\right]_{i}$ which lasted for at least the 30 -min observation period. The ET-1-induced $\left[\mathrm{Ca}^{2+}\right]_{i}$ increase was a dose-dependent effect; increases in $\left[\mathrm{Ca}^{2+}\right]_{i}$ in HeLa cells 3 min after the addition of various doses of ET-1 over the basal levels were $124.1 \pm 5.6 \%\left(10^{-14} \mathrm{M}\right), 139.6 \pm 4.0 \%$ $\left(10^{-13} \mathrm{M}\right), 169.9 \pm 17.4 \%\left(10^{-12} \mathrm{M}\right), 185.5 \pm 13.4 \%\left(10^{-11} \mathrm{M}\right)$, and $216.3 \pm 9.5 \%\left(10^{-10} \mathrm{M}\right)(n=5 ; P<0.01$ vs. control). The increase in $\left[\mathrm{Ca}^{2+}\right]_{\mathrm{i}}$ by ET-1 $\left(10^{-11} \mathrm{M}\right)$ was completely abolished by pretreatment with $3 \mathrm{mM}$ EGTA or $10^{-8} \mathrm{M}$ nicardipine. The basal $\left[\mathrm{Ca}^{2+}\right]_{\mathrm{i}}$ in $\mathrm{HEp}-2$ cells was $124.1 \pm 4.9 \mathrm{nM}(n=14)$, and ET- 1 also induced, although less effectively, $\left[\mathrm{Ca}^{2+}\right]_{i}$ increases which were dose-dependent: $107.0 \pm 0.5 \%\left(10^{-8} \mathrm{M}\right)$, $109.3 \pm 1.7 \%\left(10^{-7} \mathrm{M}\right)$, and $114.4 \pm 4.9 \%\left(10^{-6} \mathrm{M}\right)$ over the basal levels ( $n=5, P<0.01$ vs. control) (data not shown).

Under serum-free conditions, ET-1 significantly $(P<0.01)$ stimulated proliferation of $\mathrm{HeLa}$ cells in a dose-dependent manner $\left(10^{-13}-10^{-9} \mathrm{M}\right)$ and that of HEp-2 cells to the less extent $\left(10^{-8}-10^{-7} \mathrm{M}\right)$ after $72 \mathrm{~h}$ (Fig. 6). In HeLa cells, ET- 1 as low as $10^{-13} \mathrm{M}$ induced an approximate twofold increase in cell number and maximal stimulation (approximate fourfold increase) was observed at $10^{-9} \mathrm{M}$; the approximate $\mathrm{ED}_{50}$ was 3 $\times 10^{-12} \mathrm{M}$. The ET-1-induced proliferation of HeLa cells was attenuated by $10^{-8} \mathrm{M}$ nicardipine and completely inhibited by $10^{-7} \mathrm{M}$ nicardipine, whereas nicardipine $\left(10^{-8}-10^{-7} \mathrm{M}\right)$ added alone did not affect cell growth (data not shown). Addition of rabbit anti-ET-1 serum dose-dependently inhibited proliferation of HeLa cells [95.2 $\pm 1.2 \%(1: 1,000,000) ; 86.0 \pm 4.8 \%$ (1:100,000); 75.2 $\pm 6.0 \%$ (1:10,000); 37.6 $2.9 \%(1: 1,000)]$, whereas the antiserum only at a high concentration $(1: 1,000)$ significantly inhibited proliferation of HEp-2 cells (Fig. 6). Nonimmune rabbit serum $(1: 1,000)$ had no effect on prolifera-
A Hela

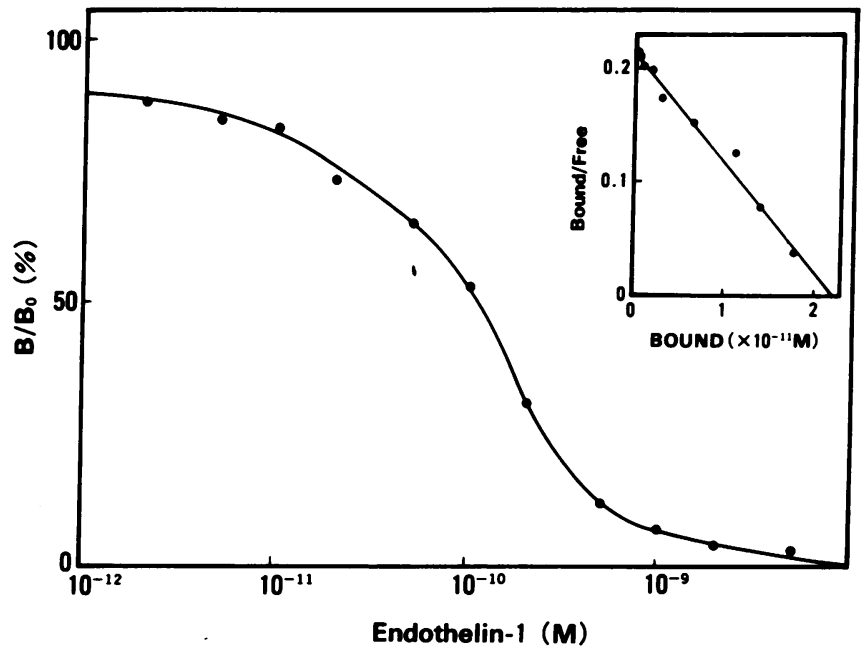

B HEp-2

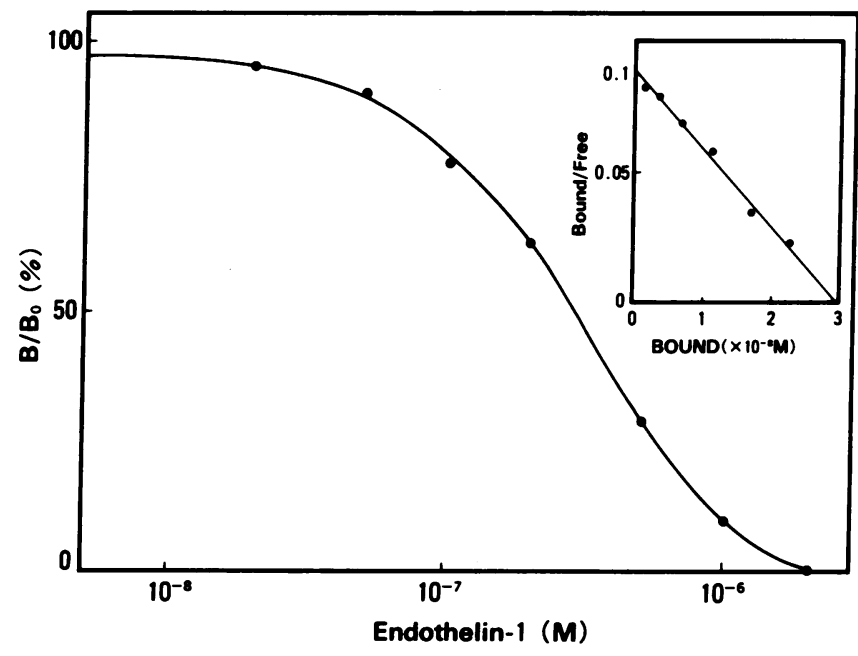

Figure 4. Competitive binding of ${ }^{125} \mathrm{I}-\mathrm{ET}-1$ to cultured $\mathrm{HeLa}(A)$ and HEp-2 $(B)$ cells by unlabeled ET-1. Each point is the mean of duplicate determinations. Specific bindings of $\mathrm{HeLa}$ and HEp-2 cells were 93 and $79 \%$ of total bindings, respectively, after $2 \mathrm{~h}$ incubation at $37^{\circ} \mathrm{C}$. (Inset) Scatchard analysis of binding data.

tion of either tumor cells. The antiserum $(1: 1,000)$ completely blocked the mitogenic effects by exogenous ET-1 $\left(10^{-11} \mathrm{M}\right.$, HeLa cells; $10^{-8}$ M, HEp-2 cells).

\section{Discussion}

In the present study, the apparent parallelism of serial dilution curves between the extracts of conditioned media from $\mathrm{HeLa}$ and HEp-2 tumor cells and standard ET-1 in ET-1 RIA as well as the time-dependent accumulation of ET-1-LI in the media strongly suggest that ET-1 and/or related peptides immunologically indistinguishable from ET-1 are released from both tumor cells. ET-1-LI release from the cells was markedly increased when cultured in the presence of FBS compared with that under a serum-free condition. This is consistent with our recent observation that the release of ET-1-LI from cultured rat 


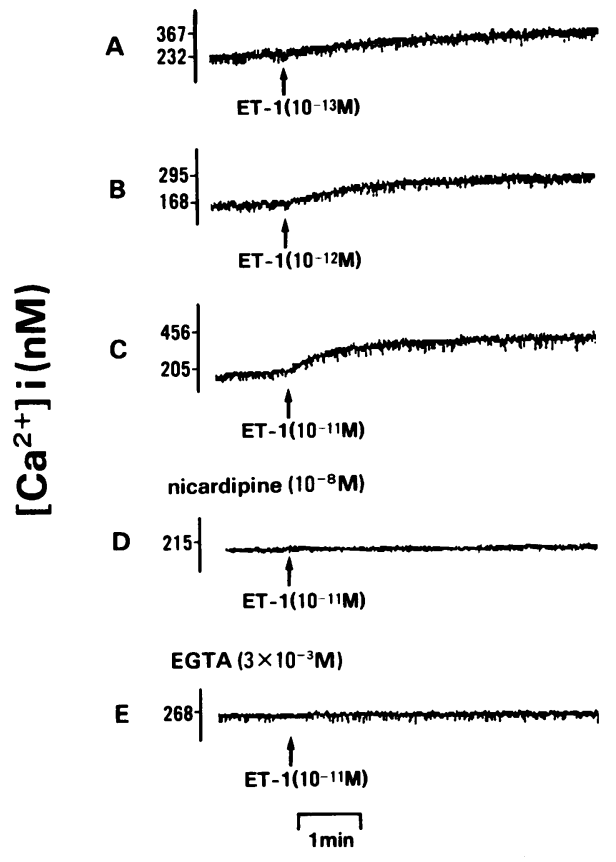

Figure 5. Representative tracings of $\left[\mathrm{Ca}^{2+}\right]_{\mathrm{i}}$ response to ET-1 in HeLa cells. Fura-2-loaded cells were challenged with various doses $\left(10^{-13}\right.$ $\left.10^{-10} \mathrm{M}\right)$ of ET-1 $(A-C)$. After pretreatment with $10^{-8} \mathrm{M}$ nicardipine $(D)$ or 3 mM EGTA $(E)$, ET-1 $\left(10^{-11} \mathrm{M}\right)$ was added.

mesangial cells is stimulated by FBS (11), suggesting the potentiating effect of some serum component(s) on synthesis and/or release of ET-1. Reverse-phase HPLC analysis coupled with RIA for ET-1 of the extracted conditioned media from HeLa cells revealed one major peak coeluting with synthetic ET-1, although the nature of the second minor one remains unknown. It may be a degradative product of ET-1. Furthermore, Northern blot analysis of poly (A) ${ }^{+}$RNA from both tumor cells demonstrated the expression of preproET-1 gene in these cells. These findings verify de novo synthesis of ET-1 by and its release from two separate tumor cell lines derived from human carcinoma (HeLa and HEp-2).

The binding study clearly demonstrates that HeLa cells have ET-1 receptors with higher affinity $\left(K_{\mathrm{d}}, 10^{-10} \mathrm{M}\right)$, whereas HEp- 2 cells have ET- 1 receptors with lower affinity $\left(K_{d}, 3\right.$ $\left.\times 10^{-7} \mathrm{M}\right)$. The binding affinity of the ET-1 receptors in HeLa cells was comparable to those $\left(K_{\mathrm{d}}, 1-4 \times 10^{-10} \mathrm{M}\right)$ of high-affinity receptors in vascular smooth muscle cells (9), cardiocytes (12), mesangial cells (13), and fibroblast (14) thus far reported. The ET-1-induced $\left[\mathrm{Ca}^{2+}\right]_{i}$ increase was gradual and sustained. This is in contrast to the ET-1-induced $\left[\mathrm{Ca}^{2+}\right]_{\mathrm{i}}$ increases in other cells, such as vascular smooth muscle cells (9), cardiocytes (12), glomerular mesangial cells (13), and fibroblasts (14); they are composed of the initial transient phase and the subsequent sustained phase. It has been suggested that the $\left[\mathrm{Ca}^{2+}\right]_{i}$ transient derives from $\mathrm{Ca}^{2+}$ mobilization from intracellular store site and the sustained $\left[\mathrm{Ca}^{2+}\right]_{\mathrm{i}}$ from $\mathrm{Ca}^{2+}$ influx $(9,12-15)$. In the present study, however, pretreatment with nicardipine or EGTA completely abolished the rise in $\left[\mathrm{Ca}^{2+}\right]_{i}$ by ET-1, suggesting that the ET-1-induced increase in $\left[\mathrm{Ca}^{2+}\right]_{i}$ may derive from $\mathrm{Ca}^{2+}$ influx through dihydropyridine(DHP)-sensitive $\mathrm{Ca}^{2+}$ channels. ET-1 dose-dependently stimulated increases in $\left[\mathrm{Ca}^{2+}\right]_{i}$ in fura-2-loaded tumor cells whose effect was far more
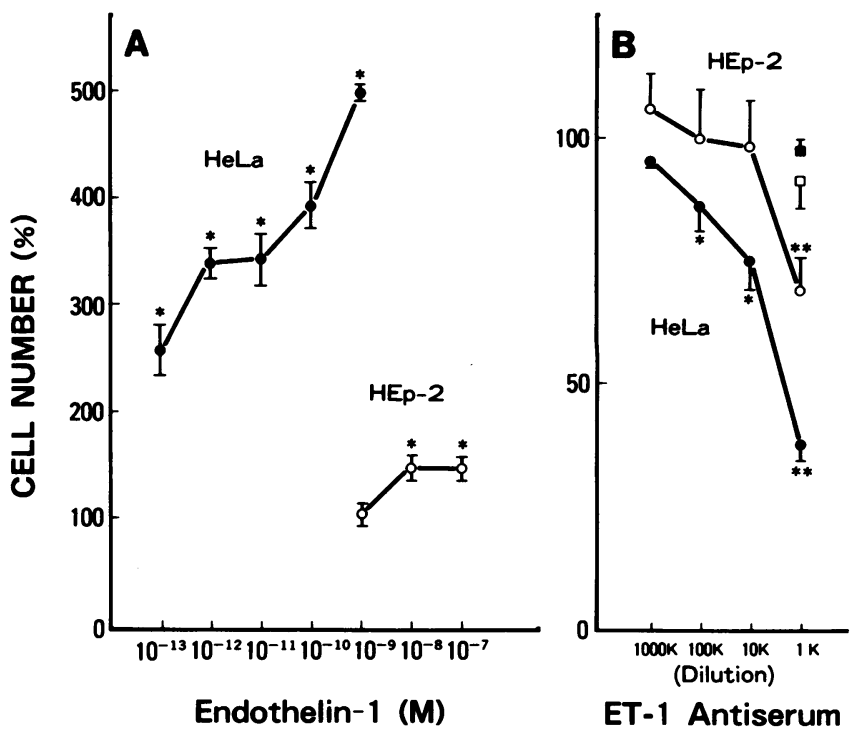

Figure 6. Effects of ET-1 and rabbit anti-ET-1 serum on growth of tumor cells. $(A)$ Quiescent HeLa (•) and HEp-2 (O) cells were incubated with indicated doses of ET-1 under a serum-free condition, and cell number was measured after $72 \mathrm{~h}$. Each point represents the percentage to control in the absence of ET-1 ( HeLa, $6.5 \pm 0.4 \times 10^{3}$ cells, $n=11$; HEp-2, $2.3 \pm 0.1 \times 10^{5}$ cells, $n=5$ ) from a single experiment; bars show SEM. ${ }^{*} P<0.01$ vs. control. $(B)$ The cells were incubated with various dilutions $(1: 1,000,000-1: 1,000)$ of rabbit ET-1 antiserum (HeLa $\bullet, \mathrm{HEp}-2 \mathrm{O})$ and nonimmune rabbit serum $(1: 1,000)$ $(\mathrm{HeLa} \backsim, \mathrm{HEp}-2 \mathrm{C})$ for $72 \mathrm{~h}$ in the presence of $0.2-3 \%$ FBS, and the cell number was measured. Each point represents the percentage to control in the absence of rabbit sera (HeLa, $1.1 \pm 0.0 \times 10^{6}$ cells, $n=8$; HEp-2, $2.3 \pm 0.2 \times 10^{5}$ cells, $n=6$ ) from a single experiment; bars show SEM. ${ }^{*} P<0.025 ;{ }^{* *} P<0.01$ vs. control.

potent in HeLa cells than in HEp- 2 cells. The differential effects of ET-1 on $\left[\mathrm{Ca}^{2+}\right]_{i}$ increase in both tumor cells may be accounted for by their different affinities of ET-1 receptors.

Synthetic ET-1 dose-dependently stimulated the proliferation of quiescent tumor cells, of which effect was also far more effective in HeLa cells than in HEp-2. These data indicate that ET-1 is a potent mitogen not only for normal cells, but for tumor cells as well. It should be noted that the minimum effective concentration to induce mitogenic effect on HeLa cells by ET-1 $\left(\sim 10^{-13} \mathrm{M}\right)$ is comparable with that of circulating ET-1 in humans $\left(\sim 6 \times 10^{-13} \mathrm{M}\right)(7)$ and far lower than those $\left(\sim 10^{-10} \mathrm{M}\right)$ to induce mitogenesis in other cells, such as rat vascular smooth muscle cells (4), fibroblasts (5), and glomerular mesangial cells (6). Furthermore, the potency of ET-1 for proliferation of the cells closely corresponded to that for $\left[\mathrm{Ca}^{2+}\right]_{i}$ increase and the ET-1-stimulated growth of these cells was inhibitable with voltage-dependent $\mathrm{Ca}^{2+}$-channel blocker. These data are compatible with the importance of $\mathrm{Ca}^{2+}$ influx for the ET-1-induced mitogenesis in rat vascular smooth muscle cells (4). Taken together, we speculate that $\mathrm{Ca}^{2+}$ influx through DHP-sensitive $\mathrm{Ca}^{2+}$ channels may be involved in the mechanism of the ET-1-induced proliferation of tumor cells.

The neutralization experiments using ET-1 antibody revealed that the proliferation of HeLa cells was inhibited more effectively than that of HEp-2 cells by coincubation with rabbit anti-ET-1 antiserum, but not with nonimmune rabbit serum. These data are consistent with the differential effects by exogenous ET-1 on $\left[\mathrm{Ca}^{2+}\right]_{\mathrm{i}}$ increases and growth of these tumor cells. 
Very recently, Kusuhara et al. have demonstrated ET-1 synthesis by other cancer cell lines and speculated a modulatory role of ET-1 in the growth of stromal cells surrounding cancer cells (16). Although they failed to detect ET-1 binding sites in only pancreatic tumor cell lines, neither the exact autocrine role of ET-1 in the tumor cell lines nor the existence of ET-1 receptors in other tumor cell lines which produce ET-1-LI have been extensively studied. The far lower affinity of ET-1 receptors and the lesser effects of ET- 1 on $\left[\mathrm{Ca}^{2+}\right]_{i}$ and cell growth in HEp-2 cells compared with those of HeLa cells in the present study might argue against the major role of ET-1 as an autocrine factor for HEp-2 cells, but for its paracrine role for the neighboring stromal cells as suggested (16). Therefore, it remains unsettled whether ET-1 production by the tumor cell lines in general acts either as an autocrine growth factor for their own cells or as a paracrine growth factor for other cells.

In conclusion, the present study demonstrates that ET-1 is synthesized by and released from human carcinoma cell lines, and that ET-1 stimulates proliferation of these cells through receptor-mediated increase in $\left[\mathrm{Ca}^{2+}\right]_{i}$, possibly derived from $\mathrm{Ca}^{2+}$ influx. Our data thus suggest that ET-1 produced by the tumor cells may function as an autocrine/paracrine growth factor for certain tumor cells.

\section{Acknowledgments}

This work was supported in part by Grants-in-Aid from the Ministry of Education, Science and Culture $(01480217,01480286,02304055)$ and the Ministry of Health and Welfare (63C-1) of Japan, and a fund from Uehara Memorial Foundation.

\section{References}

1. Yanagisawa, M., H. Kurihara, S. Kimura, Y. Tomobe, M. Kobayashi, Y. Yazaki, K. Goto, and T. Masaki. 1988. A novel potent vasoconstrictor peptide produced by vascular endothelial cells. Nature (Lond.). 332:411-415.

2. Inoue, A., M. Yanagisawa, S. Kimura, Y. Kasuya, T. Miyauchi, K. Goto, and T. Masaki. 1989. The human endothelin family: three structurally and phar- macologically distinct isopeptides predicted by three separate genes. Proc. Natl. Acad. Sci. USA. 86:2863-2867.

3. Koseki, C., M. Imai, Y. Hirata, M. Yanagisawa, and T. Masaki. 1989. Autoradiographic distribution in rat tissues of binding sites for endothelin: a neuropeptide? Am. J. Physiol. 256:R858-R866.

4. Komuro, I., H. Kurihara, T. Sugiyama, F. Takaku, and Y. Yazaki. 1988. Endothelin stimulates c-fos and c-myc expression and proliferation of vascular smooth muscle cells. FEBS (Fed. Eur. Biochem. Soc.) Lett. 238:249-252.

5. Takuwa, N., Y. Takuwa, M. Yanagisawa, K. Yamashita, and T. Masaki. 1989. A novel vasoactive peptide endothelin stimulates mitogenesis through inositol lipid turnover in Swiss 3T3 fibroblasts. J. Biol. Chem. 264:7856-7861.

6. Simonson, M. S., S. Wann, P. Mene, G. R. Dubyak, M. Kester, Y. Nakazato, J. R. Sedor, and M. J. Dunn. 1989. Endothelin stimulates phospholipase C $\mathrm{Na}^{+} / \mathrm{H}^{+}$exchange, c-fos expression, and mitogenesis in rat mesangial cells. $J$. Clin. Invest. 83:708-712.

7. Ando, K., Y. Hirata, M. Shichiri, T. Emori, and F. Marumo. 1989. Presence of immunoreactive endothelin in human plasma. FEBS (Fed. Eur. Biochem. Soc.) Lett. 245:164-166.

8. Yanagisawa, M., A. Inoue, Y. Takuwa, Y. Mitsui, M. Kobayashi, and T. Masaki. 1989. The human preproendothelin-1 gene: possible regulation by endothelial phosphoinositide turnover signaling. J. Cardiovasc. Pharmacol. 13:s13s17.

9. Hirata, Y., H. Yoshimi, S. Takata, T. X. Watanabe, S. Kumagai, N. Nakajima, and S. Sakakibara. 1988. Cellular mechanism of action by a novel vasoconstrictor endothelin in cultured rat vascular smooth muscle cells. Biochem. Biophys. Res. Commun. 154:868-875.

10. Grynkiewicz, G., M. Poenie, and R. Y. Tsien. 1985. A generation of $\mathrm{Ca}^{2+}$ indicators with greatly improved fluorescence properties. J. Biol. Chem. 260:3440-3450.

11. Sakamoto, H., S. Sasaki, Y. Hirata, T. Imai, K. Ando, T. Ida, T. Sakurai, M. Yanagisawa, T. Masaki, and F. Marumo. 1990. Production of endothelin-1 by rat cultured mesangial cells. Biochem. Biophys. Res. Commun. 169:462-468.

12. Hirata, Y., Y. Fukuda, H. Yoshimi, T. Emori, M. Shichiri, and F. Marumo. 1989. Specific receptor for endothelin in cultured rat cardiocytes. Biochem. Biophys. Res. Commun. 160:1438-1444.

13. Badr, K. F., J. J. Muray, M. D. Breyer, K. Takahashi, T. Inagami, and R. C. Harris. 1989. Mesangial cell, glomerular and renal vascular responses to endothelin in the rat kidney. J. Clin. Invest. 83:336-342.

14. Muldoon, L. L., K. D. Rodland, M. L. Forsythe, and B. E. Magun. 1989. Stimulation of phosphatidylinositol hydrolysis, diacylglycerol release, and gene expression in response to endothelin, a potent new agonist for fibroblasts and smooth muscle cells. J. Biol. Chem. 264:8529-8536.

15. Clozel, M., W. Fischli, and C. Guilly. 1989. Specific binding of endothelin on human vascular smooth muscle cells in culture. J. Clin. Invest. 83:1758-1761.

16. Kusuhara, M., K. Yamaguchi, K. Nagasaki, C. Hayashi, A. Suzaki, S. Hori, S. Handa, Y. Nakamura, and K. Abe. 1990. Production of endothelin in human cancer cell lines. Cancer Res. 50:3257-3261. 